\title{
The incremental information content of half- yearly earnings data releases by South African companies
}

\author{
R.F. Knight \\ Graduate School of Business, University of Cape Town, Rondebosch and International Management \\ Institute, Geneva, Switzerland
}

\section{J.F. Affleck-Graves}

Graduate School of Business, University of Cape Town, Rondebosch and University of Notre Dame, Indiana, USA

\begin{abstract}
In this article the information content of half-yearly earnings announcements is examined. Both annual and interim announcements are examined using the Abnormal Performance Index (API) methodology and it is shown that both sets of announcements provide incremental information. The results obtained indicate that, on average, the second-half announcements prove more informative than the second-half reports. Nevertheless, the first-half reports are still shown to provide significant incremental information. In addition, the results obtained are consistent with previous results in the sense that the API plots indicate asymmetrical behaviour with respect to 'good news' and 'bad news' announcements. Finally, it is shown that an investment strategy based on a foreknowledge of half-yearty earnings forecast errors provides higher retums than a similar strategy based on annual earnings forecast errors. This clear indication of the information content of half-yearty announcements leads the authors to speculate on whether quarterty reporting might not be in the interests of shareholders on the Johannesburg Stock Exchange.

S. Afr. J. Bus. Mgrmt. 1986, 17: 130-138
\end{abstract}

In hierdie artikel word die inligtingsinhoud van half-jaarlikse inkomste-aankondigings ondersoek. Beide jaarlikse en tussentydse aankondigings word ondersoek deur gebruik te maak van die 'Abnormal Performance Index (API)' metodologie. Daar word getoon dat beide stelle aankondigings inkrementele inligting verskaf. Die resultate dui daarop dat die aankondigings van die tweede helfte van die jaar gemiddeld meer inligting verskaf as die half-jaarlikse verslae. Desnieteenstaande, die verslae van die eerste helfte toon steeds beduidende inkrementele inligting.

Daarbenewens is die resultate in lyn met vorige resultate in dié sin dat die 'API'-kurwes asimmetriese gedrag to.v. 'goeie nuus' en 'slegte nuus' aantoon. Daar word verder getoon dat ' $n$ investeringstrategie wat berus op voorkennis van half-jaarlikse opbrengsvoorspellingsfoute 'n hoër opbrengs voorsien as 'n soortgelyke strategie wat berus op jaarlikse opbrengsvoorspellingsfoute. Hierdie duidelike aanduiding van die inligtingsinhoud van half-jaarlikse aankondigings laat die skrywers spekuleer of kwartaallikse verslae nie in die belang van aandeelhouers van die Johannesburgse Aandelemark mag woes nie.

S.-Afr. Tydstr. Bodrytsl. 1906, 17: 130-138

R.F. Kn'ta* and J.F. Amect-Graves

Graduate Sctrool of Business, University of Cape Town,

Private Bag, Rondebosch, 7700 Republic of South Africa

-To whom correspondence should be addressed

Aocepted April 1986

\section{Introduction}

The primary objective of financial reporting is to provide information useful to economic decision making. In order to establish whether the issuance of half-yearly earnings reports achieves this objective, an attempt is made to evaluate the information content of these reports. In this study a significant statistical association between the release of the reports and unusual share price behaviour is reported, which is consistent with the reports possessing information content.

In a recent publication Knight \& Affleck-Graves (1985) reported that the preliminary report has significant infor. mation content. In fact, it was suggested that this medium was the most important source of firm-specific information. The current article is aimed at extending the analysis presented by Knight \& Affleck-Graves (1985). Whereas the latter viewed the earnings process as an annual one, i.e. the preliminary announcement reports annual earnings, this article will view the process as being biannual. In other words a more detailed model of earnings expectations is defined based on half-yearly earnings.

The results indicate that half-yearly reporting has an incremental information content over annual reporting.

A certain market informational inefficiency is detected in that the reaction to the information content, by the market, is fairly sluggish and may persist for up to nine weeks in some cases.

\section{Beckground}

South African companies provide only half-yearly interim information and therefore studies of South African halfyearly reports are analogous to the American studies of quarterly reports.

No previous work on half-yearly earnings has been done in South Africa and consequently the following American studies are briefly reviewed to provide a background to the issues.

The interim reports (quarterlies) have attracted a lively research interest in the United States. It is convenient to trichotomize this work into the following categories:

(i) Time series research;

(ii) Predictive ability research;

(iii) Share return research.

The time series behaviour of quarterly earnings has been an important aspect of many issues in Accounting and Finance, such as the 'smoothing' of income (Gonedes, 1972) and the estimation of the cost of capital (Miller \& Modigliani, 1966).

The predictive ability research has concentrated on the 
ability of a quarterly earnings series to predict the following quarters earnings or the annual earnings.

Examples are research done by Brown \& Niederhoffer (1968), Brown \& Rozeff (1979), Coates (1972), and Foster (1977). Generally, these results indicate that the quarterlies improve the predictive ability of the annual earnings. This would be consistent with the interim report providing incremental information.

The final category of work has concentrated on the contemporaneous association between the release of quarterly earmings announcements and the behaviour of share returns.

In expanding the Ball \& Brown (1968) approach to quarterly announcements, Brown \& Kennelly (1972) reported an increased information content in the quarterly earnings relative to the annual series. Kiger (1972) reported a significant price and volume reaction to the release of quarterly reports which is consistent with information content. May (1971) extended the Beaver (1968) approach to quarterly announcements and reported a significant information content in these. His study was based on 105 American Stock Exchange prices over a 3-year period, and a similar method to the Beaver (1968) technique was employed with minor variations.

It should be noted that the Brown \& Kennelly (1972) approach used the API metric which requires a specification of earnings expectations, whereas the absolute residuals approach of May (1971) avoided such a specification.

The reaction of share returns to quarterly reports has been the centre of a significant academic controversy in recent years. A paper by Joy, Litzenberger \& McEnally (1977), using the API metric employed by Ball \& Brown (1968), reported a sluggish adjustment of share prices to the announcement of unanticipated changes in quarterly earnings. This non-random behaviour of price residuals immediately after the announcements was interpreted by the authors as reflecting a market inefficiency vis-à-vis the information content of these reports. Ball (1978) indicated that such behaviour could equally be attributed to a misspecification of the model from which the residuals were derived and recommended procedures to avoid such misspecifications. Watts (1978), in implementing these procedures, presented evidence of systematic abnormal returns after the quarterly earnings announcements which supports the conclusion of the Joy, et al. (1977) study.

The above summary of research is by no means exhaustive, but the studies mentioned are the prominent ones and provide good examples of the various categories of research identified. A paper by Foster (1977) tended to defy classification along lines suggested here and presented results on all three aspects referred to. The relevance of the Foster (1977) paper to this study is that it reported a significant association between the sign of the quarterly forecast error and the sign and magnitude of the annual cumulative abnormal return (CAR).

The current article would be classified in the third category mentioned in that its objective is to measure the contemporaneous association between the release of half-yearly reports and abnormal changes in share price. Changes in share price are interpreted as being the observable result of a change in market expectations. Information content is defined as the potential to change expectations, the release of a signal with information content should be associated with a change in share price. The semi-strong form of the Efficient Market Hypothesis requires that information is impounded instantaneously and therefore the information-induced price change is expected to occur immediately after the report is admitted to the public domain.

In this study it is attempted to evaluate the usefulness of interim reports while investigating the following:

(i) Price reaction to half-yearly announcements.

(ii) The association between the sign (direction) of the halfyearly earnings forecast error and the sign of the abnormal return over a similar period.

(iii) The additional information content of the half-yearly earnings series versus the annual earnings series.

(iv) The efficiency of the JSE with respect to any information content contained in the half-yearly reports.

\section{Empirical procedures}

To execute a study of this nature three types of data are required.

(i) Exact announcement dates of half-yearly results.

(ii) Weekly share price data for a reasonable period of time for all companies included.

(iii) Earnings data for these companies over a similar period.

All firms quoted in the industrial sector of the JSE for the entire period for which share data were available on the University of Cape Town data bank (viz. 2 February 1973 14 November 1980) were requested to supply the exact date of the announcement of all half-yearly results in this period. Forty-one companies responded and these constituted the sample used in this study (Appendix 1). This resulted in 420 announcements being available for the study period.

Similar procedures to those described by Knight \& AffleckGraves (1985) were employed based on the same data. These are briefly reviewed within the new context. Weekly residuals were computed over the 404-week period, 2 February 1973 through 14 November 1980, using the ordinary least squares regression technique (OLS) which took the form:

$$
R_{i t}=\widehat{\alpha}_{i}+\widehat{\beta}_{i} R_{m t}+\widehat{\varepsilon}_{i t} \quad \begin{aligned}
& t=1 \ldots 404 \\
& i=1 \ldots 41
\end{aligned}
$$

where $\widehat{\alpha}_{i}, \widehat{\beta}_{i}=$ estimates of the intercept and slope obtained from the linear regression specific to share $i$, and $\widehat{\varepsilon}_{i j}=$ an estimate of the unsystematic return on share $i$ in week $t$.

$R_{i t}=\log _{\mathrm{e}} \frac{P_{i t}+D_{i t}}{P_{i t-1}}$

where $D_{i t}=$ cash dividends on share $i$ in week $t ; P_{i t}=$ share $i$ closing price at the end of week $t$; and $R_{m t}=$ the return on the market in week $t$. The RDM 100 industrial index was used as a surrogate. The return is calculated analogously to the return on share $i$. (Prices are adjusted for all capitalization issues and share splits in week $t$.)

The usual OLS conditions must prevail to achieve consistent estimates of $\alpha_{i}$ and $\beta_{i}$. These should not constrain the application of the OLS technique in this study and are dealt with adequately by Knight \& Affleck-Graves (1985).

The Abnormal Performance Index (API) metric was employed to pool the residuals through time and across firms according to the following form:

$\operatorname{API}_{w}^{s}=\frac{1}{N} \sum_{n=1}^{N} \prod_{k=-25}^{w}\left(1+\widehat{\varepsilon}_{n k}\right)$ 
weeks relative to the annouricement (week 0 ); and $\widehat{\varepsilon}_{n k}=$ the price residual in week $k$ for announcement $\boldsymbol{n}$.

The API may be interpreted as having the value of one rand in equal amounts in all shares in the portfolio of interest at the end of week - 26 (i.e. 26 weeks prior to the release of the half-yearly report) and held to the end of an arbitrary period (say week $w$ ), excluding the market effect.

The gains and losses are considered abnormal because they are above or below what would be expected after risk adjustment. The API therefore has an expected value of one in all weeks.

As indicated by Patell (1979), the API methodology is dependent upon an assumption of an expectations model of earnings. In this article portfolios are classified as being 'good news' or 'bad news' depending on the sign of the forecast error derived as follows:

$\Delta E_{i t}=\gamma_{i}+\delta_{\mathrm{i}} \Delta E_{m t}+f_{i t} \quad i=1, \ldots, 41$

where $\Delta E_{i t}=$ percentage change in EPS in the six-month period $t$ relative to the corresponding six months $(t-1)$ in the previous year; $\Delta E_{m}=$ percentage change in the average percentage change in EPS of all industrial prices in the sixmonth period $t$ relative to the corresponding six-month period $(t-1)$ in the previous year; $\gamma_{i}, \delta_{i}=$ estimates of the intercept and slope obtained from the linear regression specific to share $i$; and $f_{i t}=$ an estimate of the unsystematic accounting return.

Again the OLS conditions apply and are not constraints on the application of the OLS technique to these data.

The amount of new information conveyed in a firm's income in a particular half year is assumed to be the difference between the actual change in income and the change conditional upon the expectation implied in (3):

$$
\begin{array}{ll}
\Delta \widehat{E}_{i t}=\gamma_{i}+\delta_{i} \Delta E_{m t} & i=1, \ldots, 41 \\
f_{i t}=\Delta E_{i t}-\Delta \widehat{E}_{i t} & t=1, \ldots, 18
\end{array}
$$

where $\Delta \widehat{E}_{i t}=$ the expected change in income for firm $i$ in half year $t ; \Delta E_{i t}=$ the actual change in income for firm $i$ in half year $t ; \Delta E_{m t}=$ the actual change in market earnings in half year $t$; and $f_{i t}=$ the earnings forecast error for firm $i$ in half year $t$.

The half year earnings forecast errors $\left(f_{i t}\right)$ were computed over a similar time period as the price residuals $\left(\widehat{\varepsilon}_{i t}\right)$ although half-yearly data were used for the former. As with the price residuals it is considered to be more efficient to compute the forecast errors over the full data set. This restricts a literal interpretation of the error as a signal, because it is based to some extent on events after the earnings of a particular half year are released.

All announcements were thus classified as 'good news' or 'bad news' depending on the sign of the earnings forecast error $\left(f_{i t}\right)$. Four hundred and twenty announcements were analysed using the API metric according to the following plan (see Table 1).

The first partition permits an analysis of half-yearly announcements generally. Thereafter the various announcements are split into sub-groups to analyse the trends making up the general pattern. Firstly the portfolios are partitioned between first and second-half announcements. The positive and negative error portfolios are further partitioned for each half depending on the sign of the previous half earnings error in the case of second-half results and that of the subsequent
Table 1 Reference to portfolios analysed

\begin{tabular}{lcccc}
\hline \multicolumn{3}{c}{ Portfolio } & \multicolumn{2}{c}{ No. of } \\
\multicolumn{1}{c}{ announcement: } & forecast error & announcements & Figure & Table \\
\hline 1. First half and & positive & 210 & 1 & 2 \\
second half & negative & 210 & & \\
(pooled) & & & & \\
2. Second half & positive & 93 & 2 & 2 \\
& negative & 117 & & \\
3. First half & positive & 97 & 3 & 2 \\
& negative & 113 & & \\
4. First half & ++ & 44 & 4 & 3 \\
& +- & 53 & & \\
& -+ & 49 & & \\
& -- & 64 & & \\
& ++ & 44 & 5 & 3 \\
5. Second half & -+ & 49 & & \\
& +- & 53 & & \\
& -- & 64 & & \\
\hline
\end{tabular}

half earnings error in the case of first-half announcements. $A$ $(+-)$ in a second-half portfolio indicates a current half negative forecast error in a firm which had a positive forecast error in the first half. Conversely a $(+-)$ in the first-half portfolio indicates a current half positive forecast error which is followed by a negative forecast error, in the subsequent half.

In total, the performance of 14 portfolios was monitored over the 50-week period surrounding the announcements, i.e. 25 weeks prior to and 24 weeks after the week of the announcement.

\section{Results and Interpretations}

Part 1: All half-yearly announcements

Initially the API analysis was based on a pooling of all halfyearly announcements, i.e. first-half announcements and annual announcements. The announcements were partitioned into those with positive half-yearly earnings forecast errors and those with negative errors. These two groups formed two hypothetical portfolios constructed 25 weeks before the relative announcement.

The weekly API's for the 50-week period surrounding the announcements are plotted in Figure 1 (for the summary of statistics see Table 2).

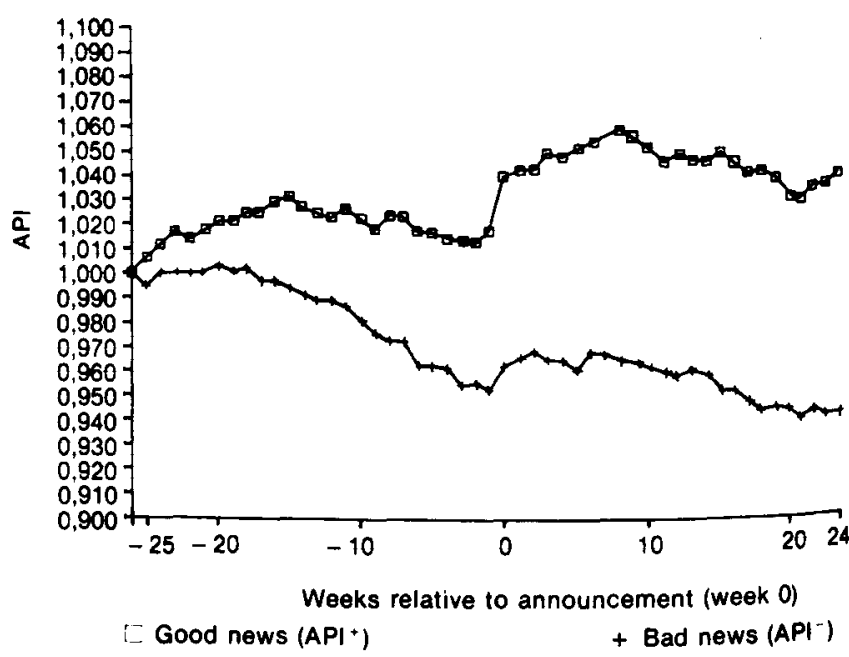

Figure 1 API plots around half-yearly releases 
Table 2 Summary statistics by week relative to half-yearly earnings announcement dates

\begin{tabular}{|c|c|c|c|c|c|c|c|c|}
\hline \multirow{2}{*}{$\begin{array}{l}\text { Week relative } \\
\text { to half-yearly } \\
\text { announcement }\end{array}$} & \multicolumn{2}{|c|}{$\begin{array}{l}\text { All announcements } \\
\text { (pooled } \\
\text { 1st and } 2 \text { nd half) }\end{array}$} & \multicolumn{3}{|c|}{$\begin{array}{c}\text { First-half } \\
\text { announcements }\end{array}$} & \multicolumn{3}{|c|}{$\begin{array}{c}\text { Second-half } \\
\text { announcements }\end{array}$} \\
\hline & $\mathrm{API}^{+}$ & $\mathrm{API}^{-}$ & $\mathrm{API}^{+}$ & $\mathrm{API}^{-}$ & $\mathrm{API}^{\mathrm{T}}$ & $\mathrm{API}^{+}$ & $\mathrm{API}^{-}$ & API $^{T}$ \\
\hline-25 & 1,006 & 0,995 & 1,007 & 0,998 & 1,002 & 1,003 & 0,995 & 0,999 \\
\hline-24 & 1,011 & 1,000 & 1,014 & 1,004 & 1,009 & 1,004 & 0,995 & 0,999 \\
\hline-23 & 1,017 & 1,000 & 1,023 & 1,003 & 1,013 & 1,006 & 0,997 & 1,001 \\
\hline-22 & 1,014 & 1,000 & 1,023 & 1,006 & 1,014 & 1,003 & 0,996 & 0,999 \\
\hline-21 & 1,017 & 1,001 & 1,021 & 1,011 & 1,016 & 1,007 & 0,995 & 1,001 \\
\hline-20 & 1,022 & 1,003 & 1,030 & 1,014 & 1,022 & 1,008 & 0,993 & 1,000 \\
\hline-19 & 1,022 & 1,001 & 1,028 & 1,017 & 1,022 & 1,008 & 0,987 & 0,997 \\
\hline-18 & 1,025 & 1,002 & 1,040 & 1,023 & 1,031 & 1,004 & 0,986 & 0,994 \\
\hline-17 & 1,026 & 0,998 & 1,040 & 1,021 & 1,030 & 1,006 & 0,980 & 0,992 \\
\hline-16 & 1,030 & 0,998 & 1,049 & 1,027 & 1,037 & 1,004 & 0,975 & 0,988 \\
\hline-15 & 1,032 & 0,995 & 1,049 & 1,023 & 1,036 & 1,005 & 0,972 & 0,987 \\
\hline-14 & 1,027 & 0,992 & 1,050 & 1,022 & 1,036 & 0,993 & 0,967 & 0,979 \\
\hline-13 & 1,025 & 0,989 & 1,051 & 1,019 & 1,034 & 0,991 & 0,961 & 0,975 \\
\hline-12 & 1,023 & 0,989 & 1,050 & 1,021 & 1,035 & 0,990 & 0,959 & 0,973 \\
\hline-11 & 1,027 & 0,987 & 1,055 & 1,017 & 1,035 & 0,995 & 0,959 & 0,975 \\
\hline-10 & 1,023 & 0,981 & 1,048 & 1,011 & 1,029 & 0,994 & 0,953 & 0,972 \\
\hline-9 & 1,018 & 0,976 & 1,042 & 1,007 & 1,024 & 0,992 & 0,949 & 0,968 \\
\hline-8 & 1,025 & 0,973 & 1,048 & 1,005 & 1,026 & 0,995 & 0,946 & 0,968 \\
\hline-7 & 1,024 & 0,973 & 1,045 & 1,001 & 1,022 & 1,001 & 0,947 & 0,972 \\
\hline-6 & 1,018 & 0,963 & 1,042 & 0,993 & 1,017 & 0,991 & 0,937 & 0,962 \\
\hline-5 & 1,017 & 0,963 & 1,041 & 0,995 & 1,017 & 0,992 & 0,936 & 0,961 \\
\hline-4 & 1,015 & 0,962 & 1,044 & 0,993 & 1,017 & 0,988 & 0,936 & 0,960 \\
\hline-3 & 1,014 & 0,955 & 1,041 & 0,986 & 1,012 & 0,990 & 0,931 & 0,958 \\
\hline-2 & 1,013 & 0,956 & 1,045 & 0,987 & 1,015 & 0,985 & 0,933 & 0,957 \\
\hline-1 & 1,018 & 0,953 & 1,051 & 0,980 & 1,014 & 0,990 & 0,933 & 0,959 \\
\hline-0 & 1,040 & 0,963 & 1,066 & 0,985 & 1,023 & 1,020 & 0,948 & 0,981 \\
\hline+1 & 1,043 & 0,966 & 1,066 & 0,992 & 1,022 & 1,027 & 0,954 & 0,987 \\
\hline+2 & 1,043 & 0,968 & 1,064 & 0,981 & 1,021 & 1,030 & 0,961 & 0,993 \\
\hline+3 & 1,050 & 0,965 & 1,069 & 0,976 & 1,021 & 1,037 & 0,962 & 0,996 \\
\hline+4 & 1,048 & 0,965 & 1,065 & 0,971 & 1,016 & 1,038 & 0,964 & 0,997 \\
\hline+5 & 1,051 & 0,961 & 1,066 & 0,965 & 1,014 & 1,044 & 0,959 & 0,998 \\
\hline+6 & 1,053 & 0,968 & 1,069 & 0,967 & 1,016 & 1,046 & 0,971 & 1,005 \\
\hline+7 & 1,057 & 0,967 & 1,071 & 0,960 & 1,013 & 1,050 & 0,975 & 1,009 \\
\hline+8 & 1,059 & 0,965 & 1,073 & 0,959 & 1,013 & 1,050 & 0,974 & 1,009 \\
\hline+9 & 1,055 & 0,964 & 1,071 & 0,952 & 1,009 & 1,047 & 0,978 & 1,009 \\
\hline+10 & 1,052 & 0,962 & 1,066 & 0,947 & 1,004 & 1,051 & 0,978 & 1,011 \\
\hline+11 & 1,046 & 0,960 & 1,056 & 0,942 & 0,997 & 1,048 & 0,977 & 1,010 \\
\hline+12 & 1,050 & 0,958 & 1,059 & 0,942 & 0,998 & 1,054 & 0,974 & 1,010 \\
\hline+13 & 1,047 & 0,960 & 1,054 & 0,945 & 0,997 & 1,054 & 0,975 & 1,011 \\
\hline+14 & 1,046 & 0,959 & 1,051 & 0,945 & 0,995 & 1,054 & 0,973 & 1,010 \\
\hline+15 & 1,050 & 0,952 & 1,055 & 0,937 & 0,994 & 1,053 & 0,966 & 1,006 \\
\hline+16 & 1,045 & 0,952 & 1,049 & 0,934 & 0,989 & 1,050 & 0,966 & 1,004 \\
\hline+17 & 1,041 & 0,947 & 1,044 & 0,930 & 0,984 & 1,047 & 0,960 & 1,000 \\
\hline+18 & 1,042 & 0,944 & 1,043 & 0,925 & 0,982 & 1,048 & 0,961 & 1,001 \\
\hline+19 & 1,038 & 0,945 & 1,042 & 0,924 & 0,981 & 1,040 & 0,963 & 0,998 \\
\hline+20 & 1,032 & 0,944 & 1,032 & 0,925 & 0,976 & 1,038 & 0,961 & 0,996 \\
\hline+21 & 1,030 & 0,940 & 1,028 & 0,921 & 0,972 & 1,035 & 0,955 & 0,991 \\
\hline+22 & 1,034 & 0,943 & 1,030 & 0,920 & 0,973 & 1,042 & 0,962 & 0,999 \\
\hline+23 & 1,036 & 0,941 & 1,037 & 0,926 & 0,979 & 1,043 & 0,956 & 0,996 \\
\hline+24 & 1,039 & 0,941 & 1,037 & 0,925 & 0,979 & 1,047 & 0,953 & 0,996 \\
\hline
\end{tabular}

The most striking feature of Figure 1 is the sharp increase in the API during the week of the announcement. For both portfolios over the entire 50-week period the change in API is greatest during this week. The change is much larger for the 'good news' portfolio. This implies that in general the half-yearly announcements are informative. Moreover there appears to be an association between the sign of the earnings forecast error and the sign of the abnormal return in the 25 weeks preceding the announcement. With a 25 -week fore- knowledge of the sign of the forecast error an investor would have been able to earn an abnormal return of $4 \%$ on the 'good news' portfolio and an abnormal return of $3,7 \%$ on the 'bad news' portfolio (if sold short). This implies that the information reported in the announcements is consistent with the information set on which shares are priced. The question of which media transmit this information remains open.

The downward drift in API, in the case of the 'bad news' 
portfolio, suggests that the market anticipates the 'news' value of the report - presumably from alternative media. This does not appear to be the case for the 'good news' portfolios, during the 10 weeks, -25 through -15 , a slight upward drift is discemable, however, the pattern seems random thereafter, culminating in an API value of 1,018 in week -1 . The conclusion to be drawn is similar to that drawn by Knight \& Affleck-Graves (1985) in respect of annual announcements, the market appears to anticipate 'bad news' to a much greater extent than 'good news'.

In order to validate the inferred positive association between the sign of the forecast error and the sign of the abnormal return to the week of the announcement a chisquare test was carried out on the $2 \times 2$ classification presented below:

\begin{tabular}{l|c|c|c|}
\multicolumn{1}{c}{} & \multicolumn{1}{c}{$\mathrm{API}_{0}>1$} & $\mathrm{APL}_{0}<1$ & \multicolumn{1}{c}{ Total } \\
\cline { 2 - 4 } Forecast error $>0$ & 118 & 72 & 190 \\
\cline { 2 - 4 } Forecast error $<0$ & 79 & 151 & 230 \\
\cline { 2 - 4 } Total & 197 & 223 & 420 \\
\hline
\end{tabular}

$D^{2}=32,9$

$\chi_{2}^{2}(0,01)=6,64$

$\therefore$ Reject $\mathrm{H}_{0}$ of independence

The test supports the conclusion that there is an association between the sign of the forecast error and the sign of the abnormal return.

\section{Part 2(a): Second-half (annual) announcements}

Knight (1983) indicated that there was a differential market reaction to first-half and second-half announcements. In order to investigate this function, the 'good news' and 'bad news' portfolios were split into first-half and second-half announcements. The second-half portfolios will be analysed in this section. The API plots are presented in Figure 2 (summary statistics Table 2). The pattern differs from that of Figure 1 in two distinct ways (1) the change in API during week 0 is much larger for the second-half announcements and (2) the $\mathrm{API}_{-1}$ values are significantly smaller than the total group. It may be concluded for the 'good news' secondhalf announcements that virtually no alternative sources of information are exploited by the market. The same is not true for the 'bad news' announcements, the information content of which is apparently anticipated by the market.

A feature of the second-half announcements which may be significant is the non-random upward drift in the API for

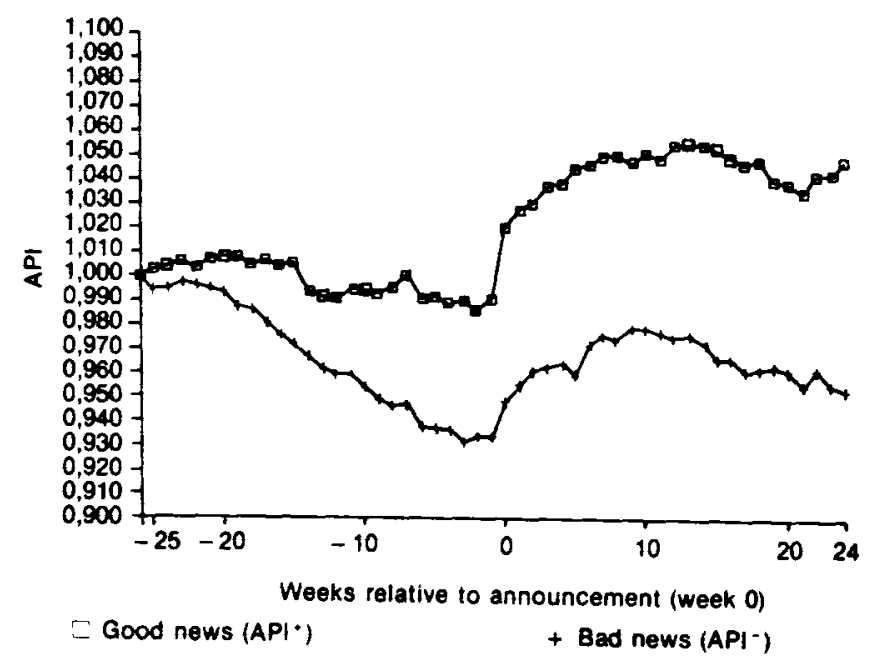

Frare 2 API plots around second-half releases about nine weeks. This drift was identified by Knight (1983), using annual forecast errors, and interpreted as being indicative of an informational inefficiency vis-à-vis the information contained in the report.

\section{Part 2(b): First-half announcements}

Attention will now be focused on the market reaction to the release of first-half earnings reports in order to complete the comparative analysis.

Before proceeding, it must be emphasized that the behaviour of the abnormal residuals before and after the announcements are not likely to be biased by the sign of the previous or subsequent half's eamings. A $2 \times 2$ chi-square test was performed to test for the association between the sign of the forecast error of first and second-half earnings:

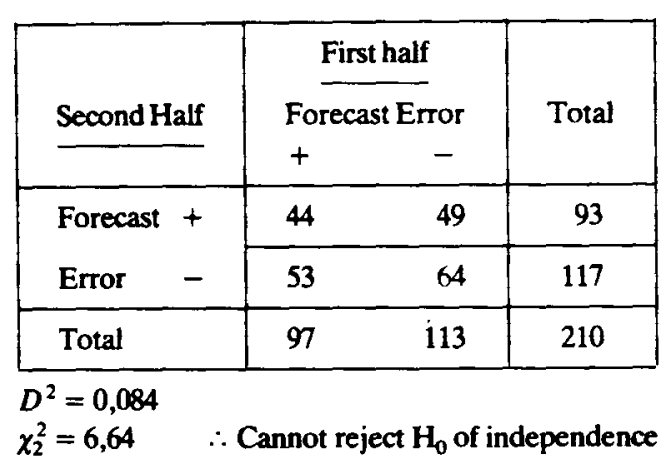

The API's for the first-half announcements are plotted on Figure 3 (summary statistics Table 2).

At first glance the results appear very different to the second-half announcements. Firstly the API for the 'good news' portfolio is considerably higher in the week prior to the announcement, 1,05 versus 0,990 for the equivalent second-half portfolio. This implies that the market receives information through more timely media consequently by the time the first-half report is released there is a smaller surprise value. This interpretation is cautioned because the increase in API occurs between weeks -25 and -18 and thereafter remains reasonably constant. Furthermore this upward drift in weeks -25 and -18 is apparent for the 'bad news' portfolio as well. This must be due to the upward drift in the API's of both the second-half portfolios (reported above) in the weeks after the announcement. If the weeks -25 to -18 are omitted and the portfolios formed in week -17 , the pattern evokes an alternative interpretation. From week -17

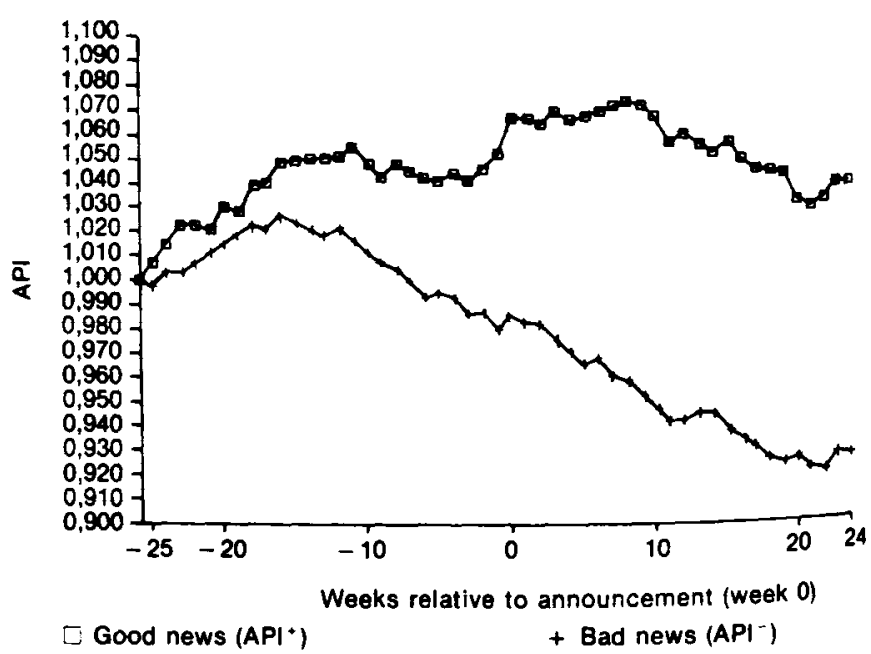

Figure 3 API plots around first-half releases 
through week -1 the API remains constant for the 'good news' announcements implying no anticipation of the information contained in the announcements. The increase in API during week 0 would be consistent with the 'good news' announcements possessing information. Conversely, mapping the API for the 'bad news' portfolio from week -17 onwards reveals a continual downward drift which persists to the end of week +25 . There is no obvious reaction to the half-yearly report.

The non-random behaviour of the residuals after the second-half earnings announcements which were tentatively interpreted as indicating an informational inefficiency, may be re-interpreted in the light of the market reaction to firsthalf earnings. The annual announcement of a firm's earnings may be followed by a series of information releases about the firm. The most obvious being the release of the annual report. Generally it is a time when various company officials make press statements regarding performance, etc. The upward drift in the weeks after the announcement may therefore be due to new information rather than sluggish

Table 3 Summary statistics by week relative to half-yearly earnings announcement dates

\begin{tabular}{|c|c|c|c|c|c|c|c|c|}
\hline \multirow{2}{*}{$\begin{array}{l}\text { Week relative } \\
\text { to half-yearly } \\
\text { announcement }\end{array}$} & \multicolumn{4}{|c|}{ First-half announcements } & \multicolumn{4}{|c|}{ Second-half announcements } \\
\hline & $\mathrm{API}^{++}$ & $\mathrm{API}^{+-}$ & $\mathrm{API}^{-+}$ & $\mathrm{API}^{--}$ & $\mathrm{API}^{++}$ & $\mathrm{API}^{-+}$ & $\mathrm{API}^{+-}$ & $\mathbf{A P I}^{--}$ \\
\hline-25 & 1,011 & 1,007 & 1,006 & 0,990 & 1,012 & 0,997 & 0,993 & 0,993 \\
\hline-24 & 1,022 & 1,012 & 1,020 & 0,995 & 1,011 & 0,999 & 1,002 & 0,988 \\
\hline-23 & 1,033 & 1,020 & 1,016 & 0,994 & 1,012 & 1,003 & 0,999 & 0,995 \\
\hline-22 & 1,028 & 1,020 & 1,015 & 0,998 & 1,011 & 0,998 & 0,994 & 0,994 \\
\hline-21 & 1,025 & 1,022 & 1,022 & 1,000 & 1,023 & 0,999 & 0,996 & 0,990 \\
\hline-20 & 1,031 & 1,034 & 1,026 & 1,004 & 1,025 & 0,997 & 1,000 & 0,986 \\
\hline-19 & 1,036 & 1,030 & 1,028 & 1,007 & 1,035 & 0,989 & 0,998 & 0,976 \\
\hline-18 & 1,042 & 1,044 & 1,029 & 1,015 & 1,027 & 0,988 & 0,995 & 0,976 \\
\hline-17 & 1,045 & 1,041 & 1,030 & 1,011 & 1,026 & 0,993 & 0,992 & 0,966 \\
\hline-16 & 1,050 & 1,055 & 1,045 & 1,009 & 1,023 & 0,992 & 0,981 & 0,964 \\
\hline-15 & 1,052 & 1,059 & 1,039 & 1,006 & 1,021 & 0,998 & 0,980 & 0,964 \\
\hline-14 & 1,048 & 1,061 & 1,037 & 1,006 & 1,009 & 0,989 & 0,975 & 0,959 \\
\hline-13 & 1,044 & 1,060 & 1,028 & 1,009 & 1,008 & 0,984 & 0,967 & 0,957 \\
\hline-12 & 1,046 & 1,055 & 1,034 & 1,007 & 1,007 & 0,981 & 0,967 & 0,956 \\
\hline-11 & 1,055 & 1,056 & 1,035 & 0,999 & 1,017 & 0,980 & 0,972 & 0,950 \\
\hline-10 & 1,056 & 1,041 & 1,026 & 0,995 & 1,024 & 0,973 & 0,969 & 0,944 \\
\hline-9 & 1,052 & 1,033 & 1,021 & 0,991 & 1,017 & 0,975 & 0,960 & 0,939 \\
\hline-8 & 1,062 & 1,039 & 1,017 & 0,990 & 1,020 & 0,980 & 0,960 & 0,935 \\
\hline-7 & 1,058 & 1,029 & 1,014 & 0,986 & 1,023 & 0,990 & 0,960 & 0,939 \\
\hline-6 & 1,056 & 1,024 & 1,006 & 0,978 & 1,023 & 0,971 & 0,947 & 0,930 \\
\hline-5 & 1,056 & 1,020 & 1,013 & 0,977 & 1,027 & 0,970 & 0,952 & 0,921 \\
\hline-4 & 1,058 & 1,019 & 1,016 & 0,969 & 1,010 & 0,978 & 0,945 & 0,927 \\
\hline-3 & 1,053 & 1,014 & 1,015 & 0,956 & 1,011 & 0,981 & 0,940 & 0,922 \\
\hline-2 & 1,053 & 1,017 & 1,015 & 0,957 & 1,011 & 0,975 & 0,936 & 0,926 \\
\hline-1 & 1,064 & 1,017 & 1,000 & 0,959 & 1,008 & 0,987 & 0,938 & 0,924 \\
\hline-0 & 1,088 & 1,021 & 1,006 & 0,961 & 1,053 & 1,008 & 0,957 & 0,935 \\
\hline+1 & 1,084 & 1,021 & 1,018 & 0,952 & 1,054 & 1,019 & 0,961 & 0,944 \\
\hline+2 & 1,078 & 1,026 & 1,026 & 0,945 & 1,056 & 1,019 & 0,967 & 0,947 \\
\hline+3 & 1,084 & 1,032 & 1,020 & 0,941 & 1,068 & 1,022 & 0,957 & 0,954 \\
\hline+4 & 1,086 & 1,022 & 1,010 & 0,939 & 1,066 & 1,026 & 0,968 & 0,954 \\
\hline+5 & 1,087 & 1,021 & 1,005 & 0,935 & 1,072 & 1,034 & 0,966 & 0,949 \\
\hline+6 & 1,093 & 1,018 & 1,008 & 0,937 & 1,071 & 1,039 & 0,977 & 0,959 \\
\hline+7 & 1,104 & 1,015 & 1,002 & 0,928 & 1,070 & 1,049 & 0,984 & 0,963 \\
\hline+8 & 1,108 & 1,021 & 0,995 & 0,930 & 1,070 & 1,046 & 0,990 & 0,958 \\
\hline+9 & 1,107 & 1,015 & 0,994 & 0,919 & 1,068 & 1,041 & 0,989 & 0,964 \\
\hline+10 & 1,096 & 1,008 & 0,988 & 0,915 & 1,072 & 1,042 & 0,991 & 0,964 \\
\hline+11 & 1,088 & 0,999 & 0,988 & 0,908 & 1,072 & 1,038 & 0,986 & 0,967 \\
\hline+12 & 1,089 & 1,003 & 0,992 & 0,904 & 1,080 & 1,040 & 0,983 & 0,965 \\
\hline+13 & 1,088 & 0,995 & 1,003 & 0,900 & 1,077 & 1,041 & 0,983 & 0,967 \\
\hline+14 & 1,085 & 0,993 & 1,006 & 0,896 & 1,075 & 1,043 & 0,979 & 0,970 \\
\hline+15 & 1,093 & 1,001 & 0,996 & 0,890 & 1,077 & 1,040 & 0,969 & 0,967 \\
\hline+16 & 1,087 & 0,993 & 0,997 & 0,884 & 1,077 & 1,036 & 0,964 & 0,973 \\
\hline+17 & 1,092 & 0,980 & 0,989 & 0,883 & 1,070 & 1,036 & 0,956 & 0,969 \\
\hline+18 & 1,093 & 0,981 & 0,987 & 0,874 & 1,075 & 1,034 & 0,953 & 0,971 \\
\hline+19 & 1,094 & 0,977 & 0,975 & 0,882 & 1,072 & 1,023 & 0,957 & 0,975 \\
\hline+20 & 1,085 & 0,966 & 0,976 & 0,882 & 1,068 & 1,025 & 0,952 & 0,974 \\
\hline+21 & 1,091 & 0,960 & 0,977 & 0,875 & 1,066 & 1,020 & 0,948 & 0,969 \\
\hline+22 & 1,085 & 0,965 & 0,979 & 0,873 & 1,084 & 1,021 & 0,953 & 0,976 \\
\hline+23 & 1,091 & 0,966 & 0,977 & 0,876 & 1,087 & 1,019 & 0,945 & 0,972 \\
\hline+24 & 1,101 & 0,959 & 0,978 & 0,884 & 1,091 & 1,025 & 0,938 & 0,969 \\
\hline
\end{tabular}


reaction to the report. This interpretation is supported by the absence of a drift in the API after the first-half 'good news' announcements. Considerably less new information is provided immediately after the first-half report.

The 'bad news' first-half portfolio API pattern after the announcement is difficult to interpret in terms of efficiency. Although there is a non-random downward drift it is not obvious that the reports have an information content to which the market is able to react to even inefficiently.

To conclude part 2 it is submitted that the second-half announcements do appear to provide more information than the first-half announcements.

\section{Part 3: Further analysis}

To further investigate the difference between first-half and second-half and between 'good news' and 'bad news' announcements the following portfolios were constructed. The announcements for each firm for each year were paired and these pairs were grouped according to the number of half-yearly reports with 'good news' and 'bad news', viz.

2 'good news'

1 'good news', 1 'bad news' $\quad$ (+-) (first half 'good news')

$(-+)$ (second half 'good news')

2 'bad news'

$$
(--) \text {. }
$$

The performance of each portfolio was then monitored (using the API metric) in the period surrounding the first and second-half announcements separately.

The 50-week API plots are presented in Figure 4 (first half) and Figure 5 (second half). Summary statistics for these four portfolios are presented in Table 3.

Attention will initially be focused on the performance of the portfolios in the six months surrounding the first-half announcements. The pattern in Figure 4 is quite clear and the performance of these portfolios is highly associated with the number of 'good' and 'bad news' reports received. As indicated above the initial upward drift in all four API's in the period week -25 through -15 may be distortive and is therefore ignored. Thereafter the $(++)$ portfolio provides little abnormal returns until the week of the announcement. After an abnormal return of $2,4 \%$ in week 0 the API reverts to a random pattern. The two portfolios with conflicting first-half and second-half signals $(+-$ and -+$)$ behave similarly including the week of announcement.

The (- -) portfolio displays a dramatic downward drift in API throughout the period, $\left(\mathrm{API}_{+24}=0,884\right)$.

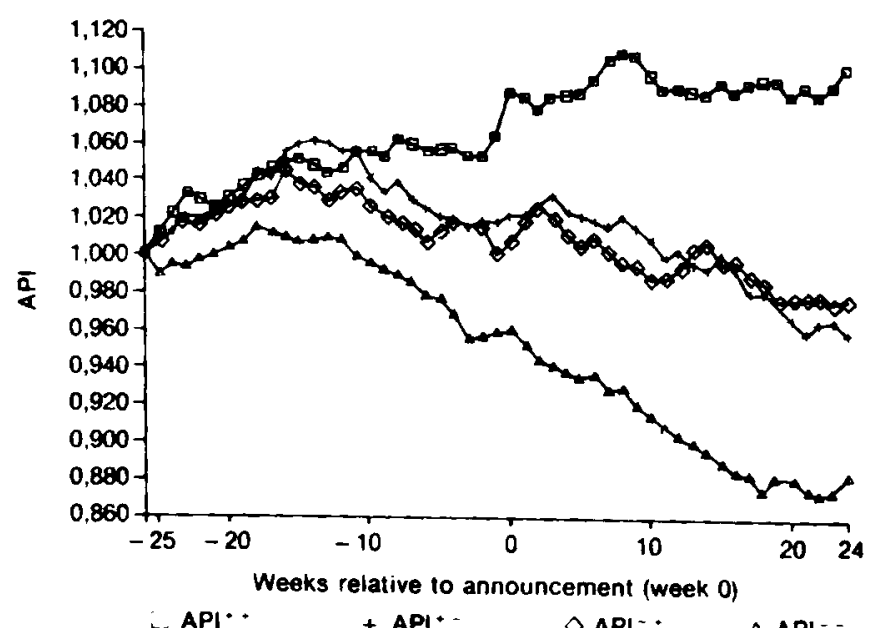

Fare 4 API plots around first-half releases

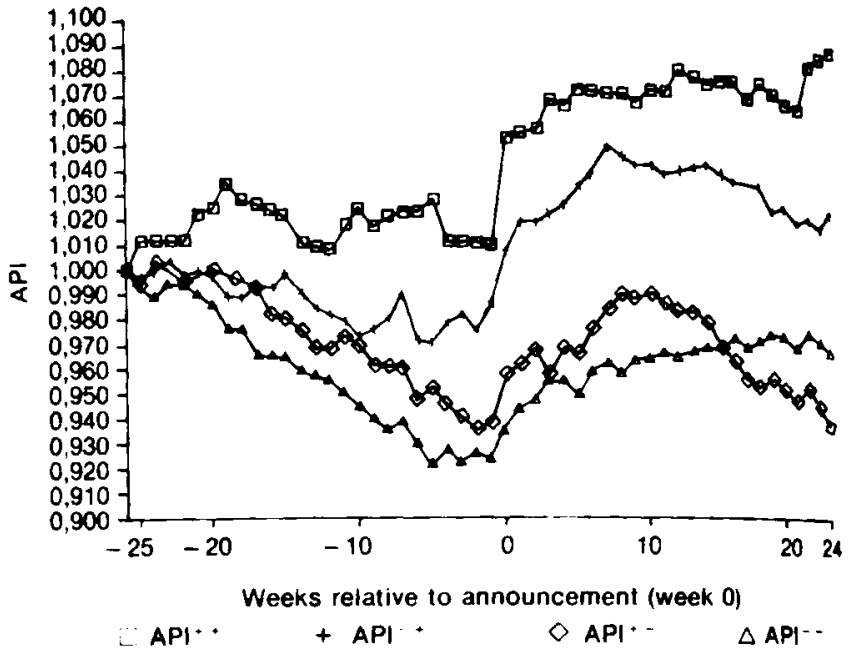

Figure 5 API plots around second-half releases

The performance of the portfolios for the 50-week period surrounding the second-half announcement provides a valuable insight into the market's reaction to accounting earnings.

The most striking feature of Figure 5 is that there appears to be an association between (1) the sign of the abnormal return and the sign of the forecast errors, and (2) the magnitude of the week 0 return and the sign of the forecast errors. The classification of portfolios according to the sign of their half-yearly forecast errors is a useful explanation of this abnormal performance.

It is interesting to note that the non-random drift in API detected after second-half earnings announcements is not evident in the $(++)$ portfolio. It appears that where the second-half report is contrary to the first-half repon, or negative, the information content appears to be sluggishly impounded. This is extremely difficult to interpret but is consistent with a certain market inefficiency. Two caveats are required, firstly as indicated by Ball (1978) the abnormal returns may be due not to an inefficiency in the market but rather to a misspecification of the market model, and secondly as indicated above other information releases may occur soon after the preliminary announcement.

The salient features of the aforegoing analysis are summarized in Table 4.

In order to evaluate whether the provision of interim reports is of any value to investors, an investment strategy based on a foreknowledge of half-yearly forecast errors is compared with a strategy based on a foreknowledge of annual forecast errors.

If the half-yearly reports are of any value the strategy based on half-yearly forecast errors should yield a higher annual abnormal return than the strategy based solely on the annual forecast errors. These results are reported in Tables 5 and 6 below.

Table 4 Summary of results

\begin{tabular}{|c|c|c|c|c|c|}
\hline \multirow[b]{2}{*}{ Portfolio } & \multicolumn{2}{|c|}{ First half } & \multicolumn{2}{|c|}{ Second half } & \multirow{2}{*}{$\begin{array}{c}\text { Performance } \\
\text { rank }\end{array}$} \\
\hline & $\mathrm{API}_{0}$ & RES $_{0}$ & $\mathbf{A P I}_{0}$ & $\mathrm{RES}_{0}$ & \\
\hline 1. ++ & 1,088 & $2,4 \%$ & 1,053 & $4,6 \%$ & 1 \\
\hline 2. +- & 1,021 & $0,4 \%$ & 0,957 & $2,0 \%$ & 2 \\
\hline 3. -+ & 1,006 & $0,6 \%$ & 1,008 & $2,0 \%$ & 3 \\
\hline 4. - - & 0,961 & $0,2 \%$ & 0,935 & $1,1 \%$ & 4 \\
\hline
\end{tabular}


Table 5 Strategy based on half-yearly forecast errors

\begin{tabular}{clc}
\hline Portfolio & \multicolumn{1}{c}{ Strategy } & Abnormal return \\
\hline $1 .(++)$ & Buy and hold for full year & $13,0 \%$ \\
$2 .(+-)$ & $\begin{array}{l}\text { Buy and hold for first six months } \\
\text { Sell short for second six months }\end{array}$ & $6,8 \%$ \\
$3 .(-+)$ & $\begin{array}{l}\text { Sell short for first six months } \\
\text { Buy and hold for second six months }\end{array}$ & $0,2 \%$ \\
$4 .(--)$ & Sell short for full year & $10,5 \%$ \\
& Average annual abnormal return & $7,625 \%$ \\
\hline
\end{tabular}

Table 6 Strategy based on annual forecast errors

\begin{tabular}{llc}
\hline Portfolio & \multicolumn{1}{c}{ Strategy } & Abnormal return \\
\hline $1 .(+)$ & Buy and hold for full year & $2,9 \%$ \\
$2 .(-)$ & Sell short for full year & $8,2 \%$ \\
& Average abnormal return & $5,5 \%$ \\
\hline
\end{tabular}

These results indicate that the half-yearly reports provide approximately $33 \%$ more information than would otherwise be available. This result is consistent with that reported by Brown \& Kennelly (1972) using a similar methodology. Before concluding it must be noted that all transaction costs have been ignored, which if accounted for would reduce the performance of the strategy based on half-yearly data.

\section{Conclusion}

In this article evidence is provided of the market reaction to half-yearly earnings reports. It seems that second-half reports are more informative than the first-half reports. The provision of half-yearly reports does, however, provide significant incremental information. The asymmetrical behaviour of the API plots to 'good news' and 'bad news' reported by Knight \& Affleck-Graves (1985) persists in the reaction to half-yearly reports. The half-yearly forecast errors appear to be more highly associated to abnormal price behaviour which indicates that the half-yearly model of income expectations may be more descriptive.

A certain market inefficiency may exist in that there is significant non-random price behaviour for a period after the release of the preliminary report in certain cases. However, it may be due to the release of additional information.

It must also be emphasized that the simultaneous disclosure of dividends may be responsible for the results presented. Almost all the earnings announcements were accompanied by a dividend announcement. Although in mitigation, dividend expectations will to an extent vary randomly across the portfolios examined in this study.

Further research would require that the potentially confounding effect of simultaneous dividend announcements be controlled.

Taken in conjunction with the results reported by Knight (1983), it seems clear that the role of published accounting information is significant in the pricing of South African shares. It is therefore imperative that accounting policy makers ensure that these reports are presented timeously. Moreover, a strong case exists to introduce more frequent reporting in South Africa, an obvious extension would be the provision of quarterly reports. Provided of course that such a provision is cost effective. The challenge to those against quarterlv earnings announcements is to prove the extent of costs; the benefits of increased interim reporting have been demonstrated clearly in this study.

\section{Acknowledgement}

The authors wish to thank the Human Sciences Research Council for financial support in this research project. Opinions expressed and conclusions arrived at are those of the authors and are not to be regarded as those of the HSRC.

\section{References}

Ball, R. 1978. Anomalies in Relationships between securities yields and yield surrogates. J. Financ. Econ., vol. 6.

Ball, R. \& Brown, P. 1968. An Empirical Evaluation of Accounting Income Numbers. J. Acc. Res., vol. 6, pp.159-178.

Beaver, W.H. 1968. The Information Content of Annual Earnings Announcements. Empirical Research in Accounting: Selected Studies, 1968. Supplement to J. Acc. Res., vol. 6, pp.67-92.

Brown, L. \& Rozeff, M. 1978. Univariate Time Series models of quarterly accounting earnings per share: A proposed model. Unpublished paper, University of Iowa, Iowa City, IA.

Brown, P. \& Kennelly, J. 1972. The Informational content of Quarterly Earnings: An Extension and some Further Evidence. J. Bus., vol. 45, pp.403-421.

Brown, P. \& Niederhoffer, V. 1968. The Predictive Content of Quarterly Earnings. J. Bus., vol. 41, pp.488-497.

Coates, R. 1972. The Predictive Content of Interim Reports A Time Series Analysis. Empirical Research in Accounting: Selected Studies, 1972. Supplement to J. Acc. Res., vol. 10, pp.132-144.

Foster, G. 1977. Quarterly Accounting Data: Time Series Properties and Predictive Ability Results. Acc. Rev., vol. L11, pp.1-21.

Gonedes, N. 1972. Income-Smoothing Behaviour under Selected Stochastic Processes. J. Bus., October, pp.570-584.

Joy, O.M., Litzenberger, R.H. \& McEnally, R.W. 1977. The Adjustment of Stock Prices to Announcements of Unanticipated Changes in Quarterly Earnings. J. Acc. Res., Autumn, pp.207225.

Kiger, G.E. 1972. An Empirical Investigation of NYSE Volume and Price Reactions to the Announcement of Quarterly Earnings. J. Acc. Res., Autumn, pp.113-128.

Knight, R.F. 1983. The Association Between Published Accounting Data and the Behaviour of Share Prices. Unpublished Ph.D. thesis, University of Cape Town, 400 p.

Knight, R.F \& Affleck-Graves, J.F. 1985. An Empirical evaluation of the effectiveness of South African investment analysts. S. Afr. J. Bus. Mgmt., vol. 16, pp.157-160.

May, R. 1971. The Influence of Quarterly Eamings Announcements on Investor Decisions as reflected in Common Stock Prices. Empirical Research in Accounting: Selected Studies, 1971. Supplement to J. Acc. Res., vol. 9

Miller, M. \& Modigliani, F. 1966. Some Estimates of the Cost of Capital to the Electric Utility Industry, 1954-1957. Am. Econ. Rev., June, pp.33-391.

Patell, J.M. 1979. The API and the Design of Experiments. J. Acc Res., vol. 12, pp.528-549.

Watts, R.L. 1978. Systematic 'Abnormal' Returns after Quarterly Earnings Announcements. J. Econ., vol. 6, pp.127-150.

\begin{tabular}{l} 
Appondix 1 \\
\hline 1. AECI Limited \\
2. African Oxygen Limited \\
3. Anglo Alpha Limited \\
4. Anglo American Industrial Corporation Limited \\
5. Barlow Rand Limited \\
6. Beares Limited \\
7. Blue Circle Limited
\end{tabular}


Appendix 1 (continued)

8. Bonmore Investments Limited

9. Boumat Limited

10. Carlton Paper Corporation Limited

11. Chemical Holdings Limited

12. Dorbyl Limited

13. Dunlop South Africa Limited

14. Edgars Stores Limited

15. Everite Limited

16. Federale Voedsel Beperk

17. Federale Volksbeleggings Beperk

18. Foschini Limited

19. Frasers Limited

20. Gallo(Africa) Limited

21. General Tyre \& Rubber Co. (South Africa) Limited

22. Huletts Corporation Limited

23. Kaap Kunene Beleggings Beperk

24. Kohler Brothers Limited
Appendix 1 (continued)

25. Malbak Limited

26. Metal Box South Africa Limited

27. Metcash Limited

28. Murray and Roberts Holdings Limited

29. O.K. Bazaars (1929) Limited

30. Otis Elevator Co. Limited

31. Pick 'n Pay Stores Limited

32. Plate Glass \& Shatterprufe Industries Limited

33. Protea Holdings Limited

34. Rennies Consolidated Holdings Limited

35. Reunert \& Lenz Limited

36. Seardel Investment Corporation Limited

37. Sentrachem Limited

38. Stewarts \& Lloyds of South Africa Limited

39. Toyota (South Africa) Limited

40. Trek Beleggings Beperk

41. Woolworths Limited 